\title{
Grain Boundary Segregation and Mechanical Properties of an Aged Ni-20Cr-18W-1Mo Superalloy at Different Temperatures
}

\author{
Han Yinben, Xue Xiangyi, Zhang Tiebang, Hu Rui, Li Jinshan \\ State Key Laboratory of Solidification Processing, Northwestern Polytechnical University, Xi'an 710072, China
}

\begin{abstract}
The influence of aging temperature $\left(200\right.$ to $800{ }^{\circ} \mathrm{C}$ ) on grain boundary segregations in a Ni-20Cr-18W-1Mo superalloy was investigated by scanning electronic microscope (SEM), transmission electron microscopy (TEM), electron microprobe analyzer (EMPA) and a mechanical testing machine. Results indicate that the grain boundary segregation critical time of sulfur and phosphorus decreases with increasing of the aging temperature. Increasing of the aging temperature has a conspicuous effect on the concentration distribution in the grain boundary and the grain core. Grain boundary concentrations of sulfur and phosphorus increase with raising the testing temperature until a peak value is obtained at 650 and $400{ }^{\circ} \mathrm{C}$, respectively, which is the essential reason to the declined mechanical properties from 200 to $600{ }^{\circ} \mathrm{C}$.
\end{abstract}

Key words: Ni-20Cr-18W-1Mo superalloy; impurity elements; grain boundary segregation; mechanical property

$\mathrm{Ni}-\mathrm{Cr}-\mathrm{W}$ based superalloys are solid-solution strengthened alloys with more than 10 elements which are widely used in quest of excellent high-temperature strength, longterm creep rupture strength and corrosion resistance ${ }^{[1-3]}$. They have found wide application in various heat resistant parts, such as combustor components of gas turbine engines, heating furnaces and components of chemical industries, especially heat exchanger tube of high temperature gas-cooled reactor ${ }^{[4]}$. However, reliability and stability are the major issues of the nickel-base alloys used in steam generators ${ }^{[5]}$. Additions of refractory elements have more effects on the microstructure and mechanical properties due to different elemental segregation behavior between a grain boundary and a grain interior. The changes in chemical composition, particularly sulfur and phosphorus, at grain boundaries inevitably affect intergranular failure, the fracture resistance and corrosion properties of many steels and superalloys, such as corrosion ${ }^{[6,7]}$ and stress corrosion cracking ${ }^{[5,8,9]}$. Such grain boundary segregation may arise from heat treatment during fabrication or from diffusion processes during component service periods at elevated temperatures ${ }^{[10]}$.
The solid-solution strengthened Ni-20Cr-18W-1Mo superalloy contains $\mathrm{Cr}$, W and Mo. During the melting process, impurity elements such as $\mathrm{P}$ and $\mathrm{S}$ are always doped in ingots. Sulfur has extremely low solid solubility $\left(<10^{-4}\right)$ and a high-grain boundary enrichment ratio $\left(\sim 10^{4}\right)$ to nickel-based alloys. Thus, sulfur significantly segregates at grain boundaries and induces embrittlement ${ }^{[11]}$. Dong et al. ${ }^{[12]}$ have studied the stress-rupture life of Ni-base alloy 718 with different sulfur contents. The stress-rupture life dramatically decreased with the increasing sulfur content and obtained a minimum at $650{ }^{\circ} \mathrm{C} / 686 \mathrm{MPa}$. Bruemmer et al. ${ }^{[13]}$ have found experimentally that sulfur is a more effective embrittling element of nickel alloys than phosphorus. Some researchers have indicated that phosphorus is a detrimental element accounting for the decrease of mechanical properties. Phosphorus promotes high-temperature cracking and hot tearing ${ }^{[14]}$. It is well known that the effects of grain-boundary segregation on properties of alloys requires determining the segregation behavior of solute atoms experimentally ${ }^{[15-17]}$.

For the Ni-20Cr-18W-1Mo superalloy, extensive work has been focused on the carbide precipitates ${ }^{[18-21]}$, super-

$\overline{\text { Received date: December } 25,2015}$

Foundation item: National Natural Science Foundation of China (51171150)

Corresponding author: Zhang Tiebang, Ph. D., Professor, State Key Laboratory of Solidification Processing, Northwestern Polytechnical University, Xi'an 710072, P. R. China, Tel: 0086-29-88491764, E-mail: tiebangzhang@nwpu.edu.cn 
lattice precipitates ${ }^{[22]}$ and deformation characteristics ${ }^{[23-25]}$. The researches on the effects of impurity elements segregation at the grain boundary have not been given any attention to. Therefore, the present work investigated the effects of impurities in Ni-20Cr-18W-1Mo superalloy on the segregation of the elements in the grain boundary. The evolution of elements segregation and their influence on the mechanical properties of the alloy were also analyzed.

\section{Experiment}

The chemical composition (wt $\%$ ) of Ni-20Cr-18W-1Mo alloy used in this work was: $\mathrm{Cr}, 19.82$; W, 18.48; Mo, 1.24; Al, 0.46; C, 0.11; B, 0.0028; La, 0.026; P, S <0.004, Bal. Ni. The process for fabrication of the wrought alloy was as follows. Firstly, the alloy was melted in a vacuum induction melting (VIM) furnace (with $1.3 \mathrm{MPa}$ pressure) and remelted twice by vacuum arc remelting (VAR). Then, the ingot was homogenized at $1200{ }^{\circ} \mathrm{C}$ for $24 \mathrm{~h}$ and furnace cooled. Finally, the ingot was hot forged and rolled to a sheet with $9 \mathrm{~mm}$ thickness at $1150{ }^{\circ} \mathrm{C}$. Then the sheet was annealed at $1260{ }^{\circ} \mathrm{C}$ for $0.5 \mathrm{~h}$, followed by water quenching (WC). All the specimens for microstructure observation and mechanical testing were cut from the annealed sheet. Then they were aged at $200,400,600,650,700,750$ and $800{ }^{\circ} \mathrm{C}$. The specimens were held for $20 \mathrm{~min}$ and ended with water quenching. SEM samples were prepared by standard metallographic techniques and the polished specimens were etched with aqua regia $\left(\mathrm{HCl}: \mathrm{HNO}_{3}=3: 1\right)$ for $120 \mathrm{~s}$ to reveal the microstructure. Elements concentrations were examined on EPMA-1720 tester equipped with SEM. Electron microprobe linear scans were used to measure the variations of each element.

For TEM, disks of $3 \mathrm{~mm}$ diameter were punched out from thin foils of $55 \mu \mathrm{m}$ thickness. Electron transparent samples for TEM investigation were prepared by electrolytic jet polishing in a solution of $10 \mathrm{vol} \%$ perchloric acid in 90 vol\% ethanol at $-30{ }^{\circ} \mathrm{C}$. TEM experiments were carried out using an FEI Tecnai $G^{2}$ F30 microscope operating at $300 \mathrm{kV}$.

Tensile tests were carried out using a Zink 150 mechanical testing machine with a strain rate maintained at $4 \times 10^{-4} \mathrm{~s}^{-1}$ under air condition. The selected testing temperatures were $25,200,400,600$ and $650{ }^{\circ} \mathrm{C}$. The samples were heated at the rate of $25{ }^{\circ} \mathrm{C} / \mathrm{min}$. When the selected temperature was reached, the samples were held for $20 \mathrm{~min}$ to make sure that a homogenous temperature distribution was achieved. After tensile tests, the samples were water quenched.

\section{Results and Discussion}

\subsection{As-annealed microstructure}

The microstructure of the as-annealed Ni-20Cr-18W-1Mo superalloy is shown in Fig.1, which is of typical fine equiaxed grains. Grain boundaries and annealing twins are obvious in the microstructures (shown in Fig.1a). A small number of primary $\mathrm{W}$-rich $\mathrm{M}_{6} \mathrm{C}$ carbides randomly disperse inside the grains with various sizes. Fig.1b shows a typical prior austenite grain boundary. The selected image shows that there are no precipitates along the grain boundary. Moreover, the average size of grains is obtained by a point-intercept method according to the standard of ASTM E112-96. Eq.(1) shows the average grain size as follows:

$$
\bar{l}=L / M P
$$

where, $\bar{l}$ is average grain size, $L$ is length of segment, $M$ is the magnification of metallograph, and $P$ is cut-off points number of every segment. The measured average grain size of the as-annealed $\mathrm{Ni}-20 \mathrm{Cr}-18 \mathrm{~W}-1 \mathrm{Mo}$ superalloy is about $54.7 \mu \mathrm{m}$.

\subsection{Critical time calculation}

When a sample is maintained at a solution treatment temperature and then cooled to a certain lower temperature, lots of vacancies are absorbed by grain boundaries ${ }^{[26]}$. The decrease in the vacancy concentration causes the decomposition of vacancy-solute complexes into vacancies and solute atoms. Therefore, a complex concentration gradient exists between the grain boundary and intracrystalline areas and leads the complexes to diffuse to the grain boundary. The diffusion causes supersaturated solute atoms to concentrate along the grain boundary. There must exist time when the complex diffusion flux to the grain boundaries balances the reverse solute diffusion flux. And the solute concentration of grain boundaries achieves a maximum value at this time. Therefore, the critical time is used to define the moment of maximum value in the isothermal process. After the solute concentration reaches peak, the de-segregation process is dominant. The level of solute concentration at grain boundaries decreases to the equilibrium concentration. The equation of critical time has been established by $\mathrm{Xu}^{[27]}$ based on the theory of Faulkner ${ }^{[15]}$ as follows:

$$
t_{\mathrm{c}}=\frac{r^{2} \ln \left(D_{\mathrm{c}} / D_{\mathrm{i}}\right)}{\delta\left(D_{\mathrm{c}}-D_{\mathrm{i}}\right)}
$$

where, $D_{\mathrm{i}}$ is diffusion coefficient for solute atom and $D_{\mathrm{c}}$

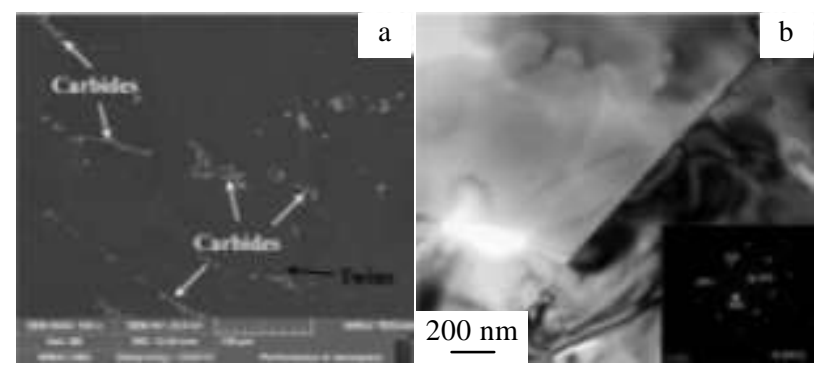

Fig.1 SEM (a) and TEM (b) images of the as-annealed Ni-20Cr18W-1Mo superalloy 
is diffusion coefficient for vacancy-solute complexes, $\delta$ is the critical time constant and $r$ is the grain radius.

Critical time is the moment that complex diffusion flux to the grain boundaries balances the reverse solute diffusion flux. The diffusion rates of complex and reverse solute are different with various temperatures. Therefore, the critical time changes with isothermal temperature. A calculation of critical time in the as-annealed Ni-20Cr-18W-1Mo superalloy can be obtained. The calculated parameters used in the critical time calculations are listed in Table 1.

Fig. 2 shows the calculated relationship between critical time and aging temperatures for sulfur and phosphorus. It can be seen from Fig. 2 that critical time of two elements decreases monotonically and rapidly with an increase in aging temperature. At the same aging temperature, critical time of phosphorus is much longer than that of sulfur. At $600{ }^{\circ} \mathrm{C}$, phosphorus critical time is about $609 \mathrm{~s}$, which is 10 times of that of sulfur. When the aging temperatures are lower than $600{ }^{\circ} \mathrm{C}$, both the critical time of sulfur and phosphorus increases rapidly. They are 7095 and $785 \mathrm{~s}$ at $500{ }^{\circ} \mathrm{C}, 170865$ and $20764 \mathrm{~s}$ at $400{ }^{\circ} \mathrm{C}$, respectively, which are considerably longer than 1200 s. When the aging temperatures are higher than $600{ }^{\circ} \mathrm{C}$, the critical time of both elements decreases rapidly. They are 86 and $8.1 \mathrm{~s}$ at $700{ }^{\circ} \mathrm{C}, 4.7$ and $0.4 \mathrm{~s}$ at $900{ }^{\circ} \mathrm{C}$, which are considerably shorter than $1200 \mathrm{~s}$.

\subsection{Elements segregation at different aging tem- peratures}

In order to study the elements segregation effects on the

Table 1 Data used in the theoretical calculations

\begin{tabular}{ccc}
\hline Parameters & Phosphorus $^{[6]}$ & Sulfur $^{[28]}$ \\
\hline$D_{\mathrm{c}} / \mathrm{m}^{2} \cdot \mathrm{s}^{-1}$ & $4.23 \times 10^{-5} \exp (-1.4 \mathrm{eV} / \mathrm{k} T)$ & $4.23 \times 10^{-5} \exp (-1.4 \mathrm{eV} / \mathrm{k} T)$ \\
$D_{\mathrm{i}} / \mathrm{m}^{2} \cdot \mathrm{s}^{-1}$ & $1.0 \times 10^{-8} \exp (-1.78 \mathrm{eV} / \mathrm{k} T)$ & $1.47 \times 10^{-4} \exp (-2.27 \mathrm{eV} / \mathrm{k} T)$ \\
$\delta$ & 47 & 357 \\
$r / \mu \mathrm{m}$ & 27.35 & 27.35 \\
\hline
\end{tabular}

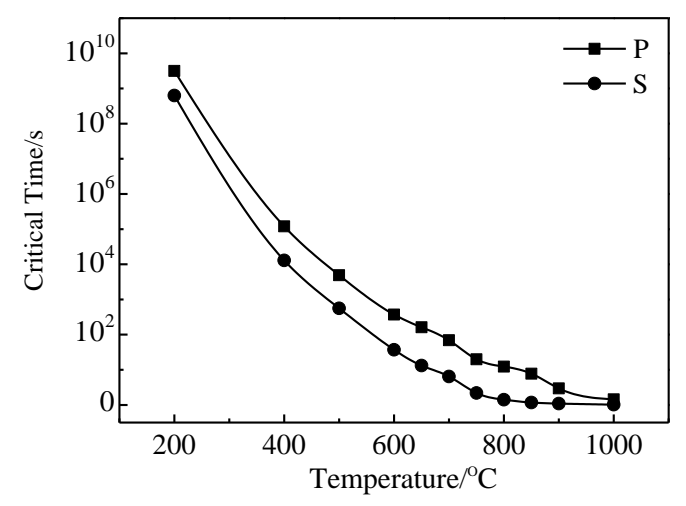

Fig.2 Calculated relationship between critical time and aging temperatures for sulfur and phosphorus in as-annealed Ni-20Cr-18W-1Mo superalloy properties of as-annealed $\mathrm{Ni}-20 \mathrm{Cr}-18 \mathrm{~W}-1 \mathrm{Mo}$ superalloy, the linear scan analysis was accomplished by EMPA. Each linear scan contains two grains. Fig. 3 shows the results of EMPA linear scan analysis of the aged samples with different temperatures. These curves have a minimum or a maximum value along the scan line for each element. Fig.3 gives the concentration profiles related to the crossing line of the grain boundary. The concentration profiles can give the width and variation of the enriched zone. According to EMPA linear scan of samples, the increasing of temperature has a conspicuous effect on the concentration distribution in the grain boundary and grain. The fluctuations of the linear scan analysis are increased for both elements by increasing the aging temperature up to $750{ }^{\circ} \mathrm{C}$ (Fig.3a 3g). But for the sample with $800{ }^{\circ} \mathrm{C}$, the fluctuations of the linear scan decrease (Fig.3h). The grain boundary concentration of sulfur and phosphorus as a function of aging temperature is shown in Fig.4. Obviously, the grain boundary concentration of sulfur increases evidently with increasing the aging temperature until a peak value $(0.0425 \mathrm{wt} \%)$ obtained at $650{ }^{\circ} \mathrm{C}$, and then decreases drastically with further increasing aging temperature. The grain boundary concentration of phosphorus has a peak value $(0.0220 \mathrm{wt} \%)$ at $400{ }^{\circ} \mathrm{C}$.

In the model of Doig and Flewitt ${ }^{[29,30]}$, the kinetics is built by solving Fick's second law for the appropriate boundary conditions. The error function solution was used to analyze the solute concentration profile in the grain boundary region for a series of small time intervals of quenching.

$$
\left(C_{\mathrm{x}}-C_{\mathrm{g}}\right) /\left(C_{\mathrm{b}}-C_{\mathrm{g}}\right)=\operatorname{erfc}\left\{x /\left[2\left(D_{\mathrm{c}} t\right)^{1 / 2}\right]\right\}
$$

where, $C_{\mathrm{x}}$ is the solute concentration at a distance $x(0 \sim 3$ $\mu \mathrm{m})$ from the grain boundary, $C_{\mathrm{b}}$ is the solute concentration at the grain core at the quenching temperature for the quenching time $t(30 \mathrm{~s}), C_{\mathrm{g}}$ is the boundary vacancy concentration after zero time and $D_{\mathrm{c}}$ is the diffusion coefficient for the complexes.

Fig.5 shows the calculated kinetic curves of sulfur and phosphorus from Eq.(3) with variation of distances from grain boundary. The dash lines stand for the position of grain boundary, which show that sulfur and phosphorus are both segregated to the grain boundaries at $400{ }^{\circ} \mathrm{C}$ in a layer about $2 \mu \mathrm{m}$. As mentioned above, the concentration of solute depends on how the critical time approaches the aging time. When the aging temperature changes from $400{ }^{\circ} \mathrm{C}$ to $600{ }^{\circ} \mathrm{C}$, the segregated degree of sulfur increases while that of phosphorus decreases dramatically. The aging temperature appears to have the greatest impact on the segregation of sulfur and phosphorus. It can be seen from Fig.5 that the kinetic curve of sulfur at $600{ }^{\circ} \mathrm{C}$ is more slowdown than that at $400{ }^{\circ} \mathrm{C}$. On the contrary, the grain boundary concentration of phosphorus at $400^{\circ} \mathrm{C}$ is higher 

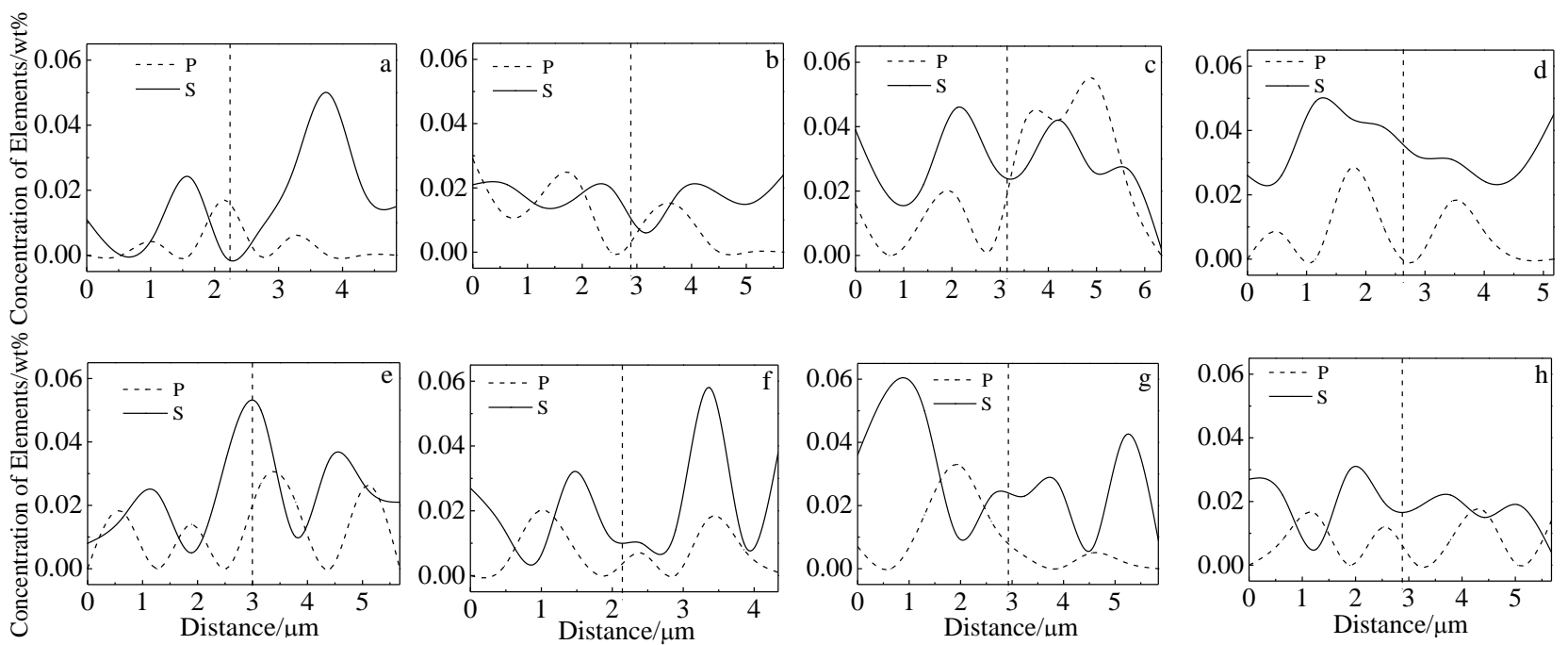

Fig.3 Depth compositional profiles of S and P near the grain boundary aged at different temperatures for $1200 \mathrm{~s}$ : (a) $20{ }^{\circ} \mathrm{C}$, (b) $200{ }^{\circ} \mathrm{C}$, (c) $400{ }^{\circ} \mathrm{C}$, (d) $600{ }^{\circ} \mathrm{C}$, (e) $650{ }^{\circ} \mathrm{C}$, (f) $700{ }^{\circ} \mathrm{C}$, (g) $750{ }^{\circ} \mathrm{C}$, and (h) $800{ }^{\circ} \mathrm{C}$

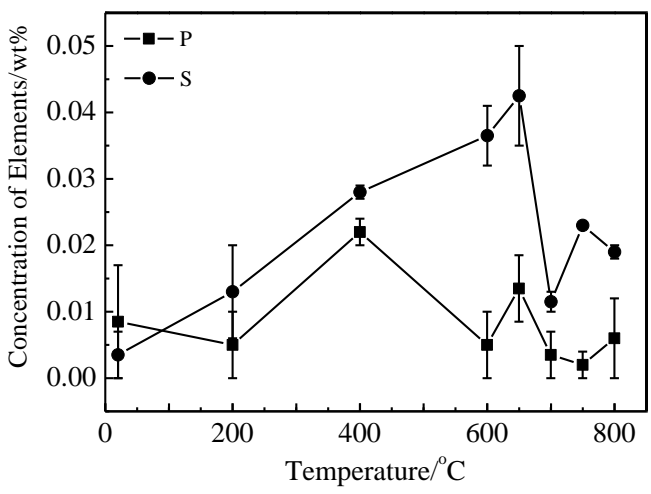

Fig.4 Grain boundary concentration of sulfur and phosphorus as a function of aging temperature

than that at $600{ }^{\circ} \mathrm{C}$. The results of EMPA and kinetic calculation indicate that sulfur and phosphorus are the main grain boundary segregation elements in the experimental $\mathrm{Ni}-20 \mathrm{Cr}-18 \mathrm{~W}-1 \mathrm{Mo}$ superalloy from $25^{\circ} \mathrm{C}$ to $600{ }^{\circ} \mathrm{C}$.

\subsection{Mechanical properties}

Mechanical properties of superalloys have to be considered during the hot working and service process, which are always related to chemical compositions and precipitations on grain boundaries. Tensile tests are used in this work to evaluate the mechanical properties of experimental alloys. Tensile property variation of Ni-20Cr-18W-1Mo superalloy as a function of aging temperature is illustrated in Fig.6. The results show that the tensile strength decreases from 855 to $710 \mathrm{MPa}$ with the increase of aging temperature. Previous research ${ }^{[31]}$ has proved that there were differences in the volume fraction of

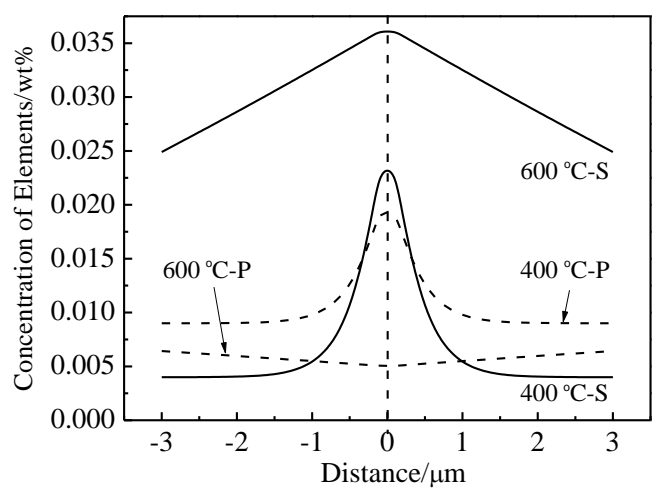

Fig.5 Calculated kinetic curves of sulfur and phosphorus from Eq.(3) with variation of distances from grain boundary

carbides after heat-treatments above $650{ }^{\circ} \mathrm{C}$ and the carbides can influence the mechanical properties of superalloys. The mechanical properties of the samples are affected by carbide's size, volume fraction and interparticle spacing $^{[32]}$. Combined with elongation results which are displayed in Fig.6 along with tensile strength, the elongation decreases with the increasing test temperature from $25^{\circ} \mathrm{C}$ to $600{ }^{\circ} \mathrm{C}$. When the temperature is higher than $600{ }^{\circ} \mathrm{C}$, the elongation increases rapidly. It shows a maximum embrittlement at $600{ }^{\circ} \mathrm{C}$ and the ductility minimum is about $43 \%$ (RA\%). Fig.7 shows the fracture morphologies of tensile fractured specimens. In the low temperature condition, the fracture mode is the mixture of the trans- and inter-granular (Fig.7a). However, as the concentrations of sulfur are extensively riched in the grain boundary region at $400{ }^{\circ} \mathrm{C}$, the inter-granular fracture mode 


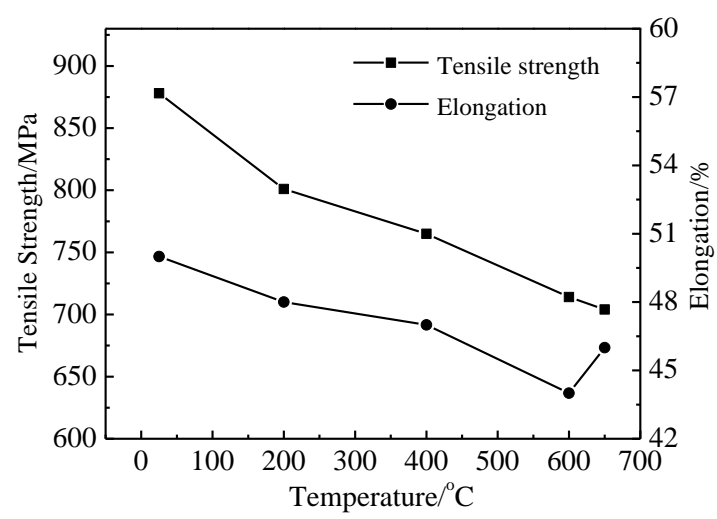

Fig.6 Effect of temperature on tensile properties of as-annealed Ni-20Cr-18W-1Mo superalloy is dominant in the tensile samples (Fig.7b). For the sample tested at $600{ }^{\circ} \mathrm{C}$, some large precipitates-induced cracks are emerge as shown in Fig.7c, which is consistent with the previous tensile test results by $\mathrm{Bai}$ et $\mathrm{al}^{[31]}$. By comparing Fig.7a, 7b and 7c, it can be found that the density of dimples on the fracture surfaces for the samples aged at $600{ }^{\circ} \mathrm{C}$ is larger than that for the samples aged at 200 and $400{ }^{\circ} \mathrm{C}$. During the hot deformation, the existence of carbide can cause the stress concentration around the carbide particles. As the stress reaches the bond strength of the matrix and carbide, microvoids nucleate ${ }^{[33]}$. From the fracture microstructures, it is obvious that the concentrations of sulfur and phosphorus affect mechanical properties depending on aging temperature. It is seen from Fig. 3 and Fig.4 that the maximum of the grain boundary concentration for sulfur and phosphorus corresponds to the low ductility

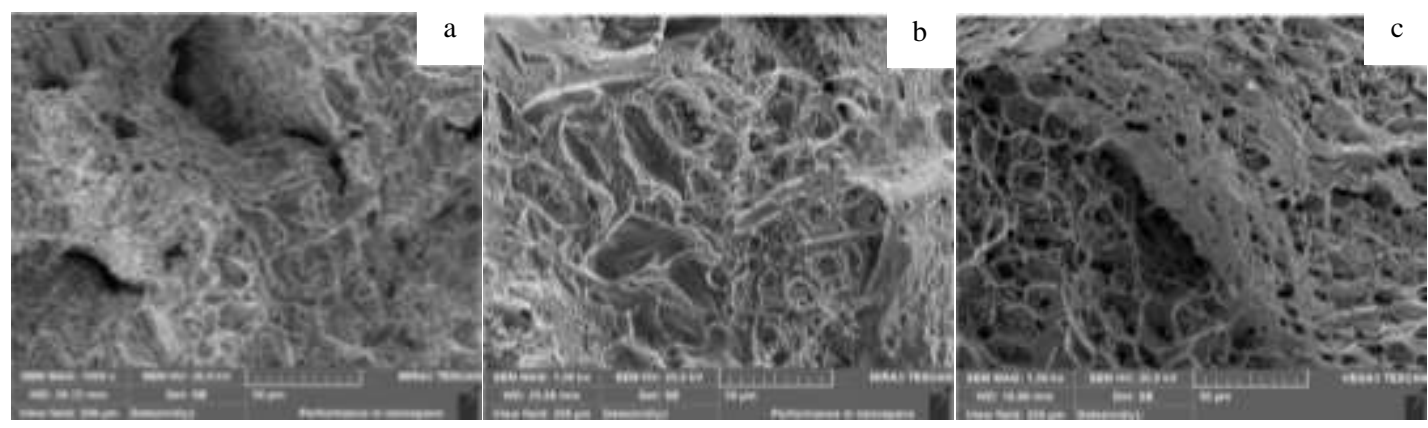

Fig.7 Fracture morphologies of tensile tested Ni-20Cr-18W-1Mo superalloy at different temperatures: (a) $200{ }^{\circ} \mathrm{C}$, (b) $400{ }^{\circ} \mathrm{C}$, and (c) $600{ }^{\circ} \mathrm{C}$

for the alloy at $400{ }^{\circ} \mathrm{C}$. When the test temperatures are lower than $400{ }^{\circ} \mathrm{C}$, the grain-boundary concentration of sulfur and phosphorus and the degree of embrittlement of this alloy increase with the increasing the test temperature. When the test temperatures range from $400{ }^{\circ} \mathrm{C}$ to $600^{\circ} \mathrm{C}$, the grain-boundary concentration of sulfur increases while that of phosphorus decreases, and the degree of embrittlement also increases with increasing the test temperature. The increase in bulk sulfur contents enhances the sensitivity to intergranular embrittlement ${ }^{[26]}$. Combined with the critical time theory and mechanical tensile test, the concentration of sulfur and phosphorus and the degree of embrittlement depend on how the critical time approaches the aging time. Fig. 2 shows that the critical time of sulfur at $400{ }^{\circ} \mathrm{C}$ to $600{ }^{\circ} \mathrm{C}$ is closer to the aging time of $1200 \mathrm{~s}$ than that at other aging temperatures. Therefore, both the grain-boundary concentration of $600{ }^{\circ} \mathrm{C}$ and the degree of embrittlement can attain maxima for aging for $1200 \mathrm{~s}$ at $600{ }^{\circ} \mathrm{C}$.

Fig. 8 shows the SEM microscopy of samples after aging testing at different temperatures. It can be clearly seen from Fig. $8 \mathrm{a}$ and $8 \mathrm{~b}$ that no dynamic recrystallization occurs during the tensile test. It is also clear that no precipitates exist at grain boundaries. XRD analysis (Fig.9) identifies that the phase compositions are chromium-rich $\gamma$ phase and tungsten-rich $\mathrm{M}_{6} \mathrm{C}$-type carbides. Bai et al. ${ }^{[31]}$ have indicated that the lamellar $\mathrm{M}_{23} \mathrm{C}_{6}$-type carbides which precipitate at $600^{\circ} \mathrm{C}$ induce premature failure of $\mathrm{Ni}-20 \mathrm{Cr}-18 \mathrm{~W}-1 \mathrm{Mo}$ superalloy. At the temperatures ranging from $600{ }^{\circ} \mathrm{C}$ to $900^{\circ} \mathrm{C}$, the anomalous yield strength could be attributed to the formation of discrete $\mathrm{M}_{23} \mathrm{C}_{6}$-type carbides. From Fig. $8 \mathrm{c}$, $8 \mathrm{~d}, 8 \mathrm{e}$ and $8 \mathrm{f}$, lots of second phase precipitates can be found along the grain boundaries after tests at temperatures ranging from $600{ }^{\circ} \mathrm{C}$ to $800^{\circ} \mathrm{C}$. Maximum embrittlement in the elevated temperature tension tests which is induced by a maximum in the grain-boundary concentration of sulfur at $500{ }^{\circ} \mathrm{C}$ has been found in experimental Ni-Cr-Fe alloy ${ }^{[28]}$. Sulfur grain boundary segregation during hot deformation at 450 and $500{ }^{\circ} \mathrm{C}$ of nickel (before recrystallization) has been also indicated by Allart et $\mathrm{al}^{[34]}$. At low temperatures $(<$ $600^{\circ} \mathrm{C}$ ), the segregation of alloying elements (such as $\mathrm{W}, \mathrm{Cr}$, Mo) does not have enough energy. It can be indicated that low ductility which is induced by sulfur and phosphorus 


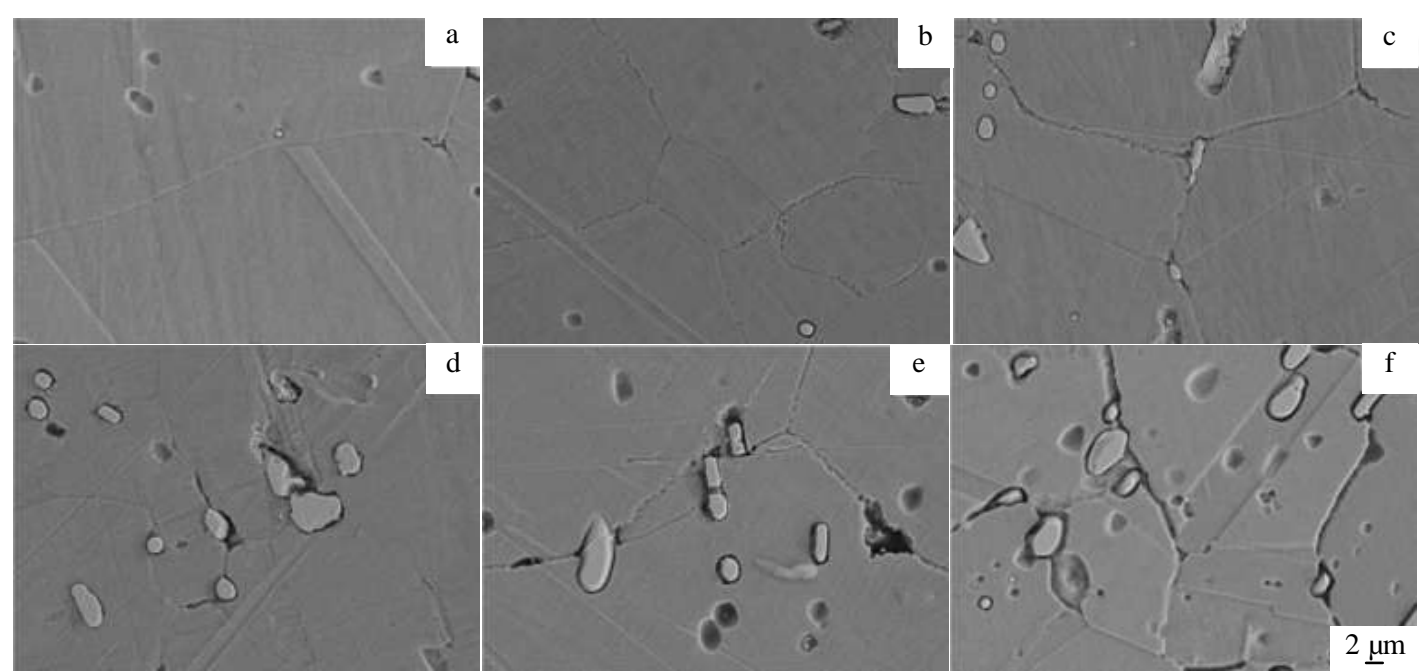

Fig. 8 SEM microstructures of as-aged $\mathrm{Ni}-20 \mathrm{Cr}-18 \mathrm{~W}-1$ Mo superalloy at different temperatures: (a) $200{ }^{\circ} \mathrm{C}$, (b) $400{ }^{\circ} \mathrm{C}$, (c) $600{ }^{\circ} \mathrm{C}$, (d) $650{ }^{\circ} \mathrm{C}$, (e) $700{ }^{\circ} \mathrm{C}$ and (f) $800{ }^{\circ} \mathrm{C}$

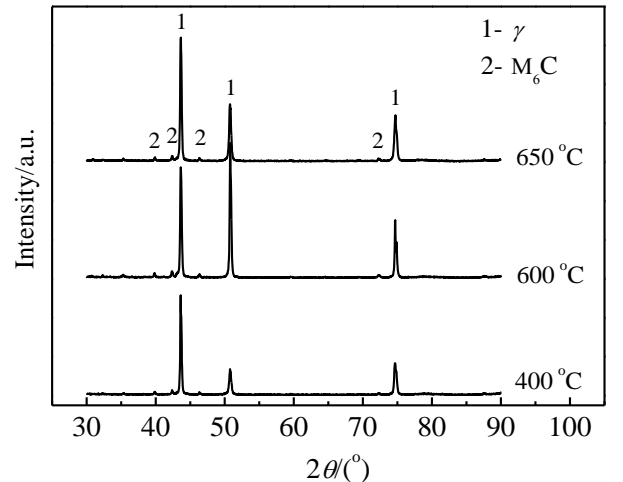

Fig.9 XRD patterns of the as-annealed Ni-20Cr-18W-1Mo superalloy aged at different temperatures for $1200 \mathrm{~s}$

grain boundary segregation is widespread in $\mathrm{Ni}$-based alloys. If more than one kind of impurity segregates to the grain boundaries, site competition and chemical interaction among impurities at grain boundaries occur ${ }^{[35]}$. During isothermal holding at $1260{ }^{\circ} \mathrm{C}$ for $1800 \mathrm{~s}$, both sulfur and phosphorus completely segregate to the grain boundaries, and the concentrations at grain boundaries are various and approach equilibrium values. When the sample is held at $600{ }^{\circ} \mathrm{C}$ for $1200 \mathrm{~s}$ before the tensile test, the grain boundary concentration of the impurities shows different levels. Combined with Fig.5, the kinetic curves show that the concentration of sulfur and phosphorus increase with the increasing the testing temperatures. It also indicates that the grain boundary concentration of sulfur is more than that of phosphorus at $600{ }^{\circ} \mathrm{C}$. From the above, the ductility of
$\mathrm{Ni}-20 \mathrm{Cr}-18 \mathrm{~W}-1 \mathrm{Mo}$ superalloy decreases with the increasing test temperature from $25^{\circ} \mathrm{C}$ to $600{ }^{\circ} \mathrm{C}$, which is ascribed to grain boundary segregation of sulfur and phosphorus. The impurities segregation and ductility variations could be reasonably explained by impurity elements grain boundary segregation, site competition and chemical interaction.

\section{Conclusions}

1) The critical time of each element in Ni-20Cr-18W1 Mo superalloy decreases monotonically and rapidly with the increase in aging temperature. However, critical time of phosphorus is much longer than that of sulfur at the same aging temperature.

2) The grain boundary concentration of sulfur increases with the increasing aging temperature until a peak value $(0.0425 \mathrm{wt} \%)$ at $650{ }^{\circ} \mathrm{C}$, and then decreases with the further increasing aging temperature. The grain boundary concentration of phosphorus has a peak value $(0.022 \mathrm{wt} \%)$ at $400{ }^{\circ} \mathrm{C}$.

3) The tensile strength and elongation values of samples decrease as the temperature increases from $25^{\circ} \mathrm{C}$ to $600{ }^{\circ} \mathrm{C}$. The tensile strength decreases from $855 \mathrm{MPa}$ to $710 \mathrm{MPa}$ and the ductility minimum is about $43 \%$ (RA\%). In addition, the increased grain boundary concentration of sulfur and phosphorus accounts for the reduced ductility of Ni-20Cr-18W-1Mo superalloy from $200{ }^{\circ} \mathrm{C}$ to $600{ }^{\circ} \mathrm{C}$.

\section{References}

1 Pataky G J, Sehitoglu H, Maier H J. Materials Characterization $[\mathrm{J}], 2013,75: 69$

2 Chen X, Yang Z Q, Sokolov M A et al. Materials Science and Engineering $A[\mathrm{~J}]$, 2013, 563: 152 
3 Tung H M, Stubbins J F. Materials Science and Engineering $A[\mathrm{~J}], 2012,538: 1$

4 Liu Y, Hu R, Li J S et al. Materials Science and Engineering $A[\mathrm{~J}], 2008,497(1-2): 283$

5 Zinkle S J, Was G S. Acta Materialia[J], 2013, 61(3): 735

6 Wang K, Si H, Yang C et al. Journal of Iron and Steel Research International[J], 2011, 18(1): 61

7 Xia S, Li H, Liu T G et al. Journal of Nuclear Materials[J], 2011, 416(3): 303

8 Briant C L. Metallurgical and Materials Transactions A[J], 1988, 19(1): 137

9 Caceras P, Ralph B, Allen G C et al. Surface and Interface Analysis[J], 1988, 12(3): 191

10 Ding R. Materials Science and Technology[J], 2010, 26(1): 36

11 Kobayashi S, Tsurekawa S, Watanabe $\mathrm{T}$ et al. Scripta Materialia[J], 2010, 62(5): 294

12 Dong J X, Xie X S, Thompson R G. Metallurgical and Materials Transactions A[J], 2000, 31(9): 2135

13 Bruemmer S M, Jones R H, Thomas M T et al. Metallurgical Transactions A[J], 1983, 14(1): 223

14 Song X L, Yuan Z X, Jia J et al. Journal of Materials Science and Technology[J], 2010, 26(9): 793

15 Faulkner R G. Journal of Materials Science[J], 1981, 16(2): 373

16 Song S H, Xu T D, Yuan Z X. Acta Metallurgica[J], 1989, 37(1): 319

17 Xu T D, Song S H. Acta Metallurgica[J], 1989, 37(9): 2499

$18 \mathrm{Hu}$ R, Bai G H, Li J S et al. Materials Science and Engineering $A[\mathrm{~J}], 2012,548: 83$

19 Bai G H, Li J S, Hu $\mathrm{R}$ et al. Materials Science and Engineering $A[\mathrm{~J}], 2011,528(6): 2339$
20 Bai G H, Hu R, Li J S et al. Rare Metal Materials and Engineering[J], 2011, 40(10): 1737 (in Chinese)

21 Han Y B, Xue X Y, Zhang T B et al. Materials Science and Engineering $A[\mathrm{~J}], 2016,667: 391$

22 Gao X Y, Hu R, Zhang $\mathrm{T}$ B et al. Materials Characterization $[\mathrm{J}], 2016,111: 86$

23 Liu Y, Hu R, Li J S et al. Materials Science and Engineering $A[\mathrm{~J}], 2009,508(1-2): 141$

24 Bai G H, Li J S, Hu R et al. Rare Metal Materials and Engineering [J], 2011, 40(7): 1300 (in Chinese)

25 Han Y B, Xue X Y, Zhang T B et al. Rare Metal Materials and Engineering [J], 2015, 44(9): 2314 (in Chinese)

26 Xu T D, Cheng B Y. Progress in Materials Science[J], 2004, 49(2): 109

27 Xu T D. Journal of Materials Science[J], 1987, 22(1): 337

28 Wang K, Xu T D, Wang Y Q et al. Philosophical Magazine Letters[J], 2009, 89(11): 725

29 Doig P, Flewitt P E J. Metallurgical Transactions A[J], 1987, 18(3): 399

30 Doig P, Flewitt P E J. Acta Metallurgica[J], 1981, 29(11): 1831

31 Bai $\mathrm{G} \mathrm{H}, \mathrm{Li} \mathrm{J} \mathrm{S}, \mathrm{Hu} \mathrm{R}$ et al. Materials Science and Engineering A[J], 2011, 528(4-5): 1974

32 Rahimian M, Milenkovic S, Sabirov I. Journal of Alloys and Compounds[J], 2013, 550(4-5): 339

$33 \mathrm{Xu} \mathrm{Z} \mathrm{F}$, Jiang L, Dong J S et al. Journal of Alloys and Compounds[J], 2015, 620: 197

34 Allart M, Christien F, Le Gall R. Acta Materialia[J], 2013, 61(20): 7938

35 Zhang Z L, Lin Q Y, Yu Z S. Materials Science and Technology[J], 2000, 16(3): 305

\title{
不同温度时效 Ni-20Cr-18W-1Mo 合金晶界偏聚及力学性能研究
}

\author{
韩寅奔, 薛祥义, 张铁邦, 胡 锐, 李金山 \\ (西北工业大学 凝固技术国家重点实验室, 陕西 西安 710072)
}

\begin{abstract}
摘 要: 采用扫描电镜 (SEM)、透射电镜 (TEM)、电子探针 (EPMA) 和高温力学试验机等手段, 研究了不同时效温度 $\left(200 \sim 800{ }^{\circ} \mathrm{C}\right)$ 对Ni-20Cr-18W-1Mo高温合金的元素晶界偏聚和力学性能的影响。结果表明, 硫、磷元素的晶界偏聚临界时间随时效温度升高而缩短; 时效温度对元素在晶界和晶内的成分分布有显著的影响; 实验合金的抗拉强度和延伸率随时效温度升高而降低。分析发现，硫、磷元素 在晶界中的含量随时效温度升高而增大直至两者分别在 650 和 $400{ }^{\circ} \mathrm{C}$ 时达到峰值, 是合金在200 600 ${ }^{\circ} \mathrm{C}$ 区间力学性能降低的重要原因。
\end{abstract} 关键词: Ni-20Cr-18W-1Mo 高温合金; 杂质元素; 晶界偏聚; 力学性能

作者简介: 韩寅奔, 男, 1986 年生, 博士生, 西北工业大学材料学院, 陕西 西安 710072, 电话: 029-88491764, E-mail: hyb_006@163.com 